\title{
VI. Diagnostic Characters of free new species of Cryptogamic Plants from Jamaica
}

\section{Thomas Taylor M.D.}

To cite this article: Thomas Taylor M.D. (1850) VI. Diagnostic Characters of free new species of Cryptogamic Plants from Jamaica , Transactions of the Botanical Society of Edinburgh, 3:1-4, 23-25, DOI: $10.1080 / 03746605009467566$

To link to this article: http://dx.doi.org/10.1080/03746605009467566

曲 Published online: 01 Dec 2010.

Submit your article to this journal $₫$

Џll Article views: 4

Q View related articles $\square$

Citing articles: 1 View citing articles ๘ 
VI. Diagnostic Characters of five new species of Cryptogamic Plants from Jamaica. By Thomas Taylor, M.D.

READ 11Th November 1847.

Leskea, Hedw.

1. L. ungustifolia (Tayl.); caule exiguo erecto subramoso, surculis flexuosis, foliis laxis distichis ex angusta basi lineari-oblongis obtusis apiculatis apice dentatis ruptinervibus substriatis surculorum ad apices arcte compressis ad basin minutis vel subnullis.

On Danaa alata (Sm.), Jamaica. In Dr. R. K. Greville's Herbarium.

Three to four lines high, pale yellowish green, shining. Leaves in eight to ten pairs, those at the top adpressed into a spike ; their inferior margin incurved at the base. This species is strongly allied to L. Nova-Hollandia (Schwaeg:), and may well be supposed to belong to the same genus even in the absence of fructification. It may be distinguished by its far smaller size, its more obtuse leaves, and by their shorter nerve. In one instance the stem is prolonged at the top into a flagelliform shoot, destitute of all but minute rudimentary leaves.

\section{Phragmicoma, Dumort.}

1. P. affixa (Tayl.); caule debili repente vage ramoso seu subdichotomo, foliis laxe imbricatis erecto-patentibus oblongo-rotundatis margine subundulatis apice parce denticulatis lobulo minuto vel subnullo, stipulis rotundatis integerrimis, calyce demum axillari oblongo-obcordato compresso ore integerrimo.

On Dancea alata (Sm.), Jamaica. In Dr. R. K. Greville's Herbarium.

Five or six lines long; very pale olive, nearly whitish: a female flower and a branch issuing from near the top of the past year's shoot. Leaves flaccid, often entire, sometimes with three or four obtuse teeth; the perichætial erect, oblong, subdentate. Capsule pale, splitting half-way down; its valves broadly ovate. The leaves by no means imbricated, flaccid, irregular in outline, variously twisted : the indistinct lobules and the large cells serve to keep the present distinct from all described species.

Radula, Nees.

1. R. Grevilleana (Tayl.); caule implexo repente subpinnato, ramis patentibus, foliis imbricatis erecto-patentibus integerrimis lobo 


\section{Dr. T. Taylor on five new species of Cryptogamic Plants.}

superiori obovato-rotundato, inferiori minuto trapezoideo, calyce demum axillari elongato ovato-oblongo apice compresso truncato, basi angustato pedicelliformi, perigoniis minutis linearibus ramorum fere ad apices usque productis lobulo monandro.

On Dancu alata (Sm.), Jamaica. In Dr. R, K. Greville's Herbarium.

Very minute, three to four lines long, olive-coloured, closely adhering to the subjacent fern; a calyx and an innovating branch terminating the preceding year's shoot. Leaves touching, more patent than erect; the perichrtial broadly elliptical, short. Capsule linear, very narrow. Perigonia on short lateral branches with ten or twelve pairs of minute imbricated ventricose leaves, each containing a spherical anther. The exserted part of the pedicel about as long as the calyx ; this is on a narrow pedicel or nearly cylindrical opake base contained within the perichrtium; it is nearly as long as the shoots. This species differs from $R$. buccinifera (Tayl.) by the smaller size, more imbricated leaves, whose tops are not so rounded, and by the calyx bulging at the base, and so by no means obconical.

\section{Plagiochila, Nees et Mont.}

1. P. sub-bidentata (Tayl.); caule repente laxe crespitoso, surculis decumbentibus subflexuosis, foliis basi imbricatis erecto-patentibus margine ventrali basi gibboso oblique ovatis acutis apice subbiciliatis, calyce oblongo ore oblique subtruncato dentato.

On Schlotheimia cirrosa (Hook.), Jamaica. Dr. J. M'Nab.

Shoots one or two inches long, scarcely one line wide, brown, attenuated above. Perigonial spikes one or two in the course of the shoots. Perichætial leaves upright, adpressed to the base of the calyx; this has a marginate angle on the upper side, and the mouth roundly truncate and split on one side. Pedicel just exposing the capsule out of the calyx. This differs from $P$. abrupta (Lindl.) by the procumbent shoots, which are longer and more attenuated above; by the wider bases of the leaves, which at the ventral margin form a crest below the stem; by the teeth of the leaves being so slender as to be mere cilia, and by the minuter cells of the leaves.

\section{Parmelia, Ach.}

1. P. ochroleuca (Tayl.); thallo laciniato-lobato, lobulis ultimis brevibus sinuato-divaricatis præmorsis retusisve albo-cinereo madore immutato tenuissime albo-reticulato subtus albido-fibrilloso, apotheciis submarginalibus concavis margine incurvo demum gemmis planis subrotundis coronato, disco castaneo subtus nudo.

Port Royal, Jamaica. Dr. J.M`Nab.

Thallus three to four inches wide, when dry waved on the surface; sinus of the lobes oblong: margin brownish; surface 
pale ash-coloured, whiter beneath, where the pale fibrils resemble those of a Peltidea. Disc of the apothecia concave when dry, flat or slightly convex when moistened and then assuming a lighter colour. The disc is naked beneath, that is, it is destitute of a thallodal layer, hence the apothecia seen by transmitted light are pellucid in the centre. Allied to Sticta Leylandii (Tayl.), which however differs by the upper surface being covered with closely set clusters of buds, by the smaller size and darker colour, by the shorter fibrils beneath the thallus, and by the apothecia receiving at length a short podetium from the thallus. The genus Sticta seems scarcely separable by a decisive character from Parmelia, and this again in another direction passes into Lecanora. 